Alma Mater Studiorum - Università di Bologna DEPARTMENT OF ECONOMICS

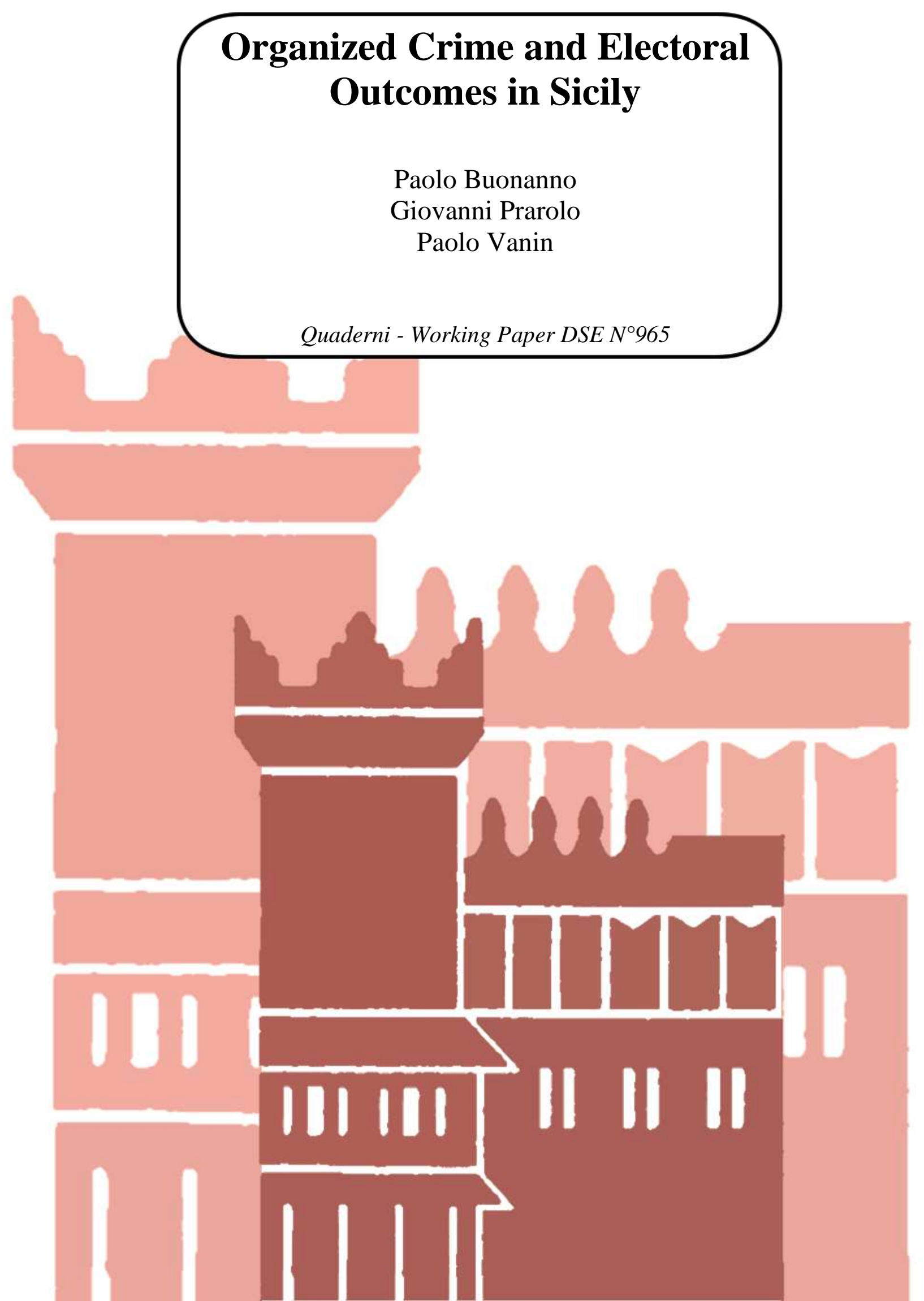




\title{
Organized Crime and Electoral Outcomes in Sicily*
}

\author{
Paolo Buonanno (U Bergamo), Giovanni Prarolo (U Bologna) and Paolo Vanin (U Bologna)
}

September 17, 2014

\begin{abstract}
This paper investigates the relationship between mafia and politics by focusing on the market for votes. It exploits the fact that in the early 1990s the Italian party system collapsed, new parties emerged and mafia families had to look for new political allies. It presents evidence, based on disaggregated data from the Italian region of Sicily, that between 1994 and 2008 Silvio Berlusconi's party, Forza Italia, obtained higher vote shares in municipalities plagued by mafia. The result is robust to the use of different measures of mafia presence, both contemporary and historical, to the inclusion of different sets of controls and to spatial analysis. Instrumenting mafia's presence by determinants of its early diffusion in the late XIX century suggests that the correlation reflects a causal link, which would be coherent with mafia's choice to back Forza Italia in exchange for favorable policies.
\end{abstract}

Keywords: Elections, Mafia-type Organizations

*Corresponding author: Paolo Buonanno, Department of Economics, University of Bergamo, Via dei Caniana 2, 24127 Bergamo, Italy. Email: paolo.buonanno@unibg.it. We gratefully acknowledge financial support from EIEF while working on this project. 


\section{Introduction}

The relationship between mafia and politics is a crucial but empirically underinvestigated issue. In this paper we explore the connection between mafia presence and party vote shares at political elections, employing municipality level data from the mafia-plagued Italian region of Sicily.

There is evidence that mafia activities exert a negative effect on development. For instance, for the case of Italy, Pinotti (2014) finds that organized crime is responsible for a $16 \%$ loss in GDP per capita over a 30 year period, Geys and Daniele (2014) show that mafia infiltration reduces the quality of local politicians (measured by their average education level), and Barone and Narciso (2014) document mafia's ability to divert a substantial amount of public funds assigned to poor areas. A majority of voters might then in principle support a successful fight against the mafia, if this is not too costly. Yet mafia's persistence (documented for the Italian case, among others, by Buonanno et al., 2014), suggests that either at some point further fighting organized crime has higher social costs than benefits, or that, even when the reverse is true, something in the political process prevents the majority that would benefit from a sharp fight against the mafia from giving rise to effective policies in such direction.

One possible reason, which is in line with theoretical results as well as with anecdotal, judicial and empirical evidence, is that mafia organizations distort electoral outcomes by intervening in the market for votes. As emphasized by Gambetta (1993), transactions in such market are typically illegal, so mafia-type organizations may step in, collect votes (through either threats or rewards to citizens) and supply them to politicians in exchange for favors, with the latter ranging from diversion of public funds and procurement contracts to favorable legislation and lenient prosecution.

The political economic literature has considered vote buying from different perspectives, ranging from an individualized market for votes (Piketty, 1999, 2000; Dekel et al., 2008) to bribes (Snyder, 1991) and to campaign contributions by lobbies (Grossman and Helpman, 1996), but these studies are only indirectly related to mafia's intervention in the market for votes. More directly related are contributions that look at how interest groups condition politicians' choices and, most importantly, how they control citizens' votes. Esteban and Ray (2006) notice that lobbies' willingness to pay to influence politicians depends both on the relevance of their interests and on their wealth. From this point of view, mafia's wealth may render it politically influential even when its interests are socially harmful. Baland and Robinson (2008) develop a model in which landlords control their workers' vote and show that before the introduction of the secret ballot in Chile, right-wing parties representing the interests of landed aristocracy received more votes where patron-client relationships were stronger. Their model may be useful in the present context because one of the ways in which the mafia controls votes is through patron-client relationships, which are particularly strong in areas in which it exercises an almost 
monopsonistic role in the labor market, thus being an employer to which citizens have only few and costly alternatives. Acemoglu et al. (2013) propose a model in which nonstate armed actors bring votes to politicians, who therefore have a lower incentive to fight them. They also provide empirical evidence on the infuence of paramilitaries on elections in Colombia, which is relevant here because violence or its threat is yet another way in which mafia controls votes and thereby buy active support or at least tolerance by politicians.

Most closely related to the present investigation is De Feo and De Luca (2013), who formalize a probabilistic voting model in which mafia sells votes to the party that has more core supporters and is thus expected to win. The reason is that such party needs to offer less public goods to convince swing voters and is thus able to retain higher rents from being in office, so its willingness to pay for votes is higher. They also show empirical evidence from Sicily, according to which after 1970 the Christian Democrats (the majority party until 1992) obtained more votes in Sicilian municipalities plagued by mafia. Their findings are in accordance with judicial evidence of organic relationships between the Sicilian Mafia and several Italian politicians. To pick up just two prominent examples from the Christian Democrats, Vito Ciancimino, mayor of Palermo (Sicily's capital city) in the early 1970s, was later sentenced to eight years of prison for mafia association, and Giulio Andreotti, several times Prime Minister of Italy, was not convicted due to prescription, but according to the court maintained stable relationships with the mafia until 1980.

Due to widespread corruption scandals and to changes in international affairs, in the early 1990s the Italian political landscape experienced an earthquake. All major parties, including the Christian Democrats, disappeared, broke down into several minor parties or changed name. At the same time, mafia's fight against its enemies inside the state reached its peak of violence with the assassination in 1992 of two judges, Giovanni Falcone and Paolo Borsellino, who had been responsible for a maxi-trial against the mafia in the late 1980s. In response to such assassinations, many major mafia lords were captured and sentenced. The mid 1990s thus witnessed the emergence of new political leaders and of new mafia lords, who had to find a new balance between fighting each other and collaborating with each other. The most important of the new political leaders, Silvio Berlusconi, founded his Forza Italia party in 1993 and became Italy's prime minister in 1994. His connections with the mafia were often discussed by the press. According to a court ruling in 2012, in the 1970s he paid mafia for protection, fearing the kidnapping of his son. In the same years, he hired a Sicilian mafioso, Vittorio Mangano, to tend his horses. The latter, with a known previous criminal record, had been introduced to Berlusconi by Marcello Dell'Utri, one of his closest collaborators, later co-founder of Forza Italia, who in 2014 was sentenced to seven years of jail for mafia connections. Forza Italia and the center-right coalition always won a majority at political elections in Sicily between 1998 and 2008. In 2001 they won in each and every electoral district, obtaining all of Sicily's 
61 parliamentary seats and leaving none to the centre-left coalition. According to Antonino Giuffre', a mafia boss turned informer, the mafia supported Forza Italia since 1993, in exchange for help in resolving its judicial problems (The Guardian, "Berlusconi implicated in deal with godfathers", 5 December 2002).

This evidence motivates our research question: using disaggregated data on mafia diffusion in Sicily and on vote shares between 1994 and 2008, can we find evidence of a systematic link between the Sicilian mafia and party vote shares at political elections? If the answer is positive, can we interpret any such correlation as evidence of mafia's intervention in the market for votes?

To answer these questions, we employ party vote shares pooled across electoral years (because we look for stable connections) and we exploit information on firms and real estate properties seized to the mafia to measure its presence. Our first finding is that in mafia-plaugued municipalities Berlsconi's party and coalition obtained significantly higher vote shares, whereas the centre-left coalition obtained significantly lower vote shares. Of course, while interesting, a correlation is by no means a proof of collusion. An important issue is that contemporaneous mafia measures may be endogenous, either because they are driven by omitted variables correlated with vote shares, or because they are influenced by the political activity of the different parties and hence by their vote shares.

To address endogeneity we employ two strategies. First, we use lagged rather than contemporaneous measures of mafia presence. Second, we instrument current mafia presence by its historical determinants. The first lagged measure dates back to 1987. It is taken from De Feo and De Luca (2013) and it is based on a report by the military police (Carabinieri) to a parliamentary committee (Comando Generale dell'Arma dei Carabinieri, 1987). The second lagged measure dates back to 1900 and it is based on a map of early mafia distribution elaborated by Cutrera (1900). We find that Forza Italia's vote shares are positively and significantly correlated with mafia's presence in 1987, but not in 1900, whereas votes to the centre-left are unrelated to both. Our instrumental variable strategy is based on Buonanno et al. (2014), who find that early mafia's distribution in the late XIX century was positively related to sulfur presence, difference in elevation within a municipality and agro-ecological suitability for the cultivation of cereals. Using these instuments we find that Berlusconi's party vote share is positively and significantly related to all of the above mentioned mafia measures, both contemporaneous and lagged, whereas votes for the centre-left are negatively but not significantly related to instrumented mafia presence. As Forza Italia became the new majoritarian party in Sicily, this evidence is consistent with De Feo and De Luca's (2014) theory and with the Sicilian mafia supplying votes to Berlusconi's party.

The remainder of this paper is organized as follows. Section 2 describes the data, Section 3 presents the empirical analysis and Section 4 concludes. 


\section{Data}

\subsection{Mafia Data}

We use historical and contemporary data on the presence of the mafia in Sicilian municipalities.

Our data on the early diffusion of mafia in Sicily comes from the work of Cutrera (1900), which is described in details in Buonanno et al. (2014). For each municipality, Cutrera assessed the intensity of mafia activity on a four-point scale ranging from none, to low, intermediate and high. ${ }^{1}$ For the sake of comparability with other mafia variables, we use a dummy taking value one if mafia activity was present at any level (low, intermediate or high) and zero if it was absent. Cutrera's data have been extensively used in previous historical and sociological studies on the Sicilian mafia (see, e.g., Gambetta, 1993). ${ }^{2}$ The geographical distribution of the Sicilian mafia in the late XIX century, depicted in Figure 1, shows that it was more present in the Western part of the island, particularly in the areas around Palermo and Agrigento. This pattern is largely consistent with numerous reports from historians and early mafia experts (see Lupo, 1993 and Sylos Labini, 2003, among others). Descriptive statistics of this and all the other variables described in this section are collected in Table 1.

To have a more recent measure of mafia distribution, which is still predetermined with respect to our dependent variables, and therefore attenuates problems of simultaneity, we rely on data presented in De Feo and De Luca (2013), who flag Sicilian municipalities as mafia-intense if they were stronghold of main mafia families according to a 1987 military police report. This variable correlates 0.33 with the dummy based on Cutrera's data.

Finally, our measures of today's mafia presence in Sicilian municipalities exploit information on firms and real estate properties seized by the Italian judicial authority to the mafia. ${ }^{3} \mathrm{We}$ define two dummies, taking value one if by the end of 2011 at least one firm or at least one real estate property, respectively, had been seized to the mafia in a given municipality (source: Agenzia del Demanio). As a more encompassing measure of mafia presence, we also define a third dummy, taking value if either of the previous two is equal to one, whose distribution is depicted in depicted in Figure 2. It is worth noticing that over the considered period firms and real estate properties were seized in around $22 \%$ and $40 \%$ of Sicilian municipalities, respectively, and in more than $41 \%$ of them at least a firm or a real estate property were seized. The pairwise correlation between contemporary and predetermined measures of mafia presence ranges between 0.20 and 0.34 .

\footnotetext{
${ }^{1}$ A careful analysis of splits and merges of Sicilian municipalities throughout the last 120 years allows improving on Buonanno et al. (2014) and assigning Cutrera's measure to 337 rather than 285 of today's municipalities.

${ }^{2}$ An alternative source of information on the early incidence of mafia activity is represented by the DamianiJacini parliamentary enquiry (Damiani, 1885).

${ }^{3}$ Law n. 646 (September 1982), known as Law "Rognoni - La Torre" rules the seizure of firms and real estate properties belonging to mafia-type organizations.
} 


\subsection{Electoral Data}

Our main dependent variable is the share of votes obtained at national elections by Forza Italia, the party founded and led by Silvio Berlusconi since 1994. The electoral data is taken from Istituto Cattaneo's "Atlante storico-elettorale d'Italia" (Corbetta and Piretti, 2009), which collects all Italian electoral results from 1861 to 2008 . We use data on elections in the period 19942008, specifically elections in 1994 (the first election with the new spectrum of political parties, namely the dissolution of Christian Democrats, DC, and the birth of Forza Italia), 1996, 2001, 2006 and 2008, although in this last round Forza Italia merged with other center-right minor parties relabeling itself as "Il Popolo delle Libertà" ("The People of Freedoms"). In particular, our main dependent variable is the share of votes obtained by Forza Italia in each municipality, averaged throughout the period. Its distribution is shown in Figure 3. As an alternative dependent variable, we use the fraction of votes obtained by the aggregate of centre-left parties.

Since its creation, Forza Italia obtained remarkable results in Sicily, with $33 \%$ share, compared to the $21 \%$ share at the national level, in 1994. It gained momentum until 2001, when it got $36 \%$ share and a striking 61 out of 61 Sicilian electoral districts. After a relative drop to $30 \%$ in 2006, it reached $47 \%$ after the merge in 2008. Forza Italia has been sometimes described as the natural close substitute of Christian Democrats for electors that, after 1993, have seen their favorite party disappearing. However, the correlations between the share obtained by Christian Democrats in 1992 and the share obtained by Forza Italia in subsequent elections is virtually zero, both in municipalities with and without mafia presence. A formal regression (with or without province fixed effects) of the vote share obtained by Forza Italia in 1994 on the share of Christian Democrats in 1992, mafia presence and their interaction delivers coherent results. This suggestive evidence indicates Forza Italia did not simply replace the Christian Democrats: it was a new political force, which in principle might have chosen to fight the mafia or to come to terms with it. Analogously, mafia families faced the choice whether to back this new party or look for alternative political alliances.

\subsection{Controls and Instruments}

In our empirical analysis we control for several variables at the municipal level. Specifically, we focus on factors that might influence both the political leaning of municipalities and the presence of mafia, in order to reduce the risk that the econometric analysis picks up spurious correlations. First we have a full set of nine provincial dummies, which take into accounts possible local political enclaves and any factor that is constant at the province level. We then have a series of municipality-level socioeconomic controls from the Italian 2001 census. This series includes population density, which ideally controls for differential voting behavior between rural and urban areas. Immigration rate is included because Forza Italia (allied in the North of Italy 
with the nationalistic Northern League) always proposed stricter rules for immigration, with respect to centre-left parties. We add the share of working age population with at least high school because in the Italian political tradition more educated people vote for centre-left parties. Another variable from the census is the unemployment rate, which can be correlated both with mafia presence (since mafia can easily hire from the pool of unemployed people the manpower needed in the organization of extortions and other mafia-related criminal activity) and with votes for Forza Italia, whose workhorse in many rounds of elections was the creation of jobs. We also add average altitude to the set of our controls. From the 2001 census we also have value added per capita, although at the level of Local Systems of Labor (which is a higher aggregation level with respect to municipalities, with around 11 municipalities on average for each Local System). Finally, we construct a measure of tax evasion/social capital, based on the share of families that do not pay the tax for the possession of television (source: RAI).

In the second part of the empirical analysis we rely on an instrumental variable technique, as we suspect that each of our measures of mafia may suffer, for different reasons, from issues of either measurement error or reverse causality, and as an omitted variable bias can never be excluded with absolute certainty. We use instruments that in Buonanno et al. (2014) proved to be genuinely correlated with some measures of mafia and can be safely be excluded from the second stage. In particular these instruments are the number of sulfur mines in each municipality in 1886 from Squarzina (1963), the suitability of soil for the cultivation of cereals, obtained by the FAO-GAEZ database, and the difference in altitude within a municipality, from ISTAT, the Italian statistical office. The first instrument is at the core of Buonanno et al. (2014), where the strong predictive power of sulfur in terms of early mafia diffusion is extensively documented. The second proxies for the existence of historical large landholdings, another mafia predictor according to historians. The third takes into account different demand and supply factors, all in the direction of boosting the presence of mafia. Examples are the possibility for outlaws to better hide due to impervious terrain, the vulnerability of cattle during transhumance and the high cost of policing.

\section{Empirical strategy}

This section presents the empirical analysis of the effect of mafia presence on electoral outcomes. As discussed above, we rely on several contemporary and historical measures of the mafia presence in each Sicilian municipality and we relate these measures to the share of votes obtained at national elections by Forza Italia, the party founded and led by Silvio Berlusconi since 1994. In particular, our main dependent variable is the average share of votes obtained at national elections by Forza Italia over the period 1994-2008. The latter is due to data availability. Indeed, both measures of mafia (contemporary and historical) and several controls, 
presented in the previous sections, are time-invariant and thus this force us to rely on the crosssection dimension Nevertheless, we enrich our baseline estimates in order to assess the extent of measurement errors, omitted variables bias and reverse causality.

Our main estimating equation is

$$
s h_{i}=\beta \text { mafia }_{i}+\gamma^{\prime} X_{i}+\phi_{p}+\varepsilon_{i}
$$

where $s h_{i}$ is the average share of votes obtained at national elections by Forza Italia over the period 1994-2008 in municipality $i$, mafia $_{i}$ is the indicator for mafia presence as presented above, $X_{i}$ is a set of control variables; $\phi_{p}$ are province-fixed effects and finally, $\varepsilon_{i}$ is an error term. The set of observables $X_{i}$ comprises the other demographic and socioeconomic determinants of electoral outcome discussed above.

OLS estimates on equation (1) are presented in Table 2 and Table 3. In particular, we first estimate the raw correlation between the share of votes for Forza Italia and mafia presence and then we progressively add to our baseline specification first province-fixed effect and secondly the set of control variables. Table 2 presents our results when using contemporary measure of mafia presence, while Table 3 show our findings when we rely on historical and predetermined measure of mafia. Our result is that the different measures of mafia are positively and, almost always, significantly correlated with the share of votes obtained by Forza Italia at national elections. This relationship is overall robust across the different definitions of mafia and even across alternative specifications of determinants and controls of electoral outcome. According to these findings, mafia presence is associated with a $4 \%-5 \%$ increase of the share of votes obtained by Forza Italia when we use contemporary mafia measure, while the historical presence of mafia is associated to a $2 \%$ increase of the share of votes obtained by Forza Italia.

Turning to the control variables, it emerges that immigration rate, unemployment rate, the share of individuals with high school diploma and our measure of tax evasion do not exert a significant effect on electoral outcome. Population density and GDP per capita are positively and significantly correlated with our dependent variable.

However, there could be several reasons why our measures of mafia presence may systematically correlate with the share of votes obtained by Forza Italia, some of which may not be adequately captured by our control variables. Therefore, identifying causality requires a source of exogenous variation in our mafia measures, an issue that we tackle in the next section.

\subsection{Robustness checks}

In this section, we perform several alternative specifications designed to test the robustness of our estimates.

First, as a falsification test, we re-run our regressions by using as our dependent variable the 
share of votes obtained by the centre-left coalition, rather than the share of votes obtained by Forza Italia. The results obtained from this set of regressions, presented in tables 4 and 5, show that the mafia presence is negatively and significantly correlated to the share of votes obtained by the centre-left coalition.

Second, while the above analysis suggests that omitted variables are not driving our results, as an additional check we control for possible spatial effects. There is no reason to believe that mafia's activity follows the administrative boundaries of municipalities. Mafia bosses may indeed offer protection and practice extortion in neighboring municipalities, whose territory they control. They may also establish agreements with other mafia families, who control different territories. There may therefore be relevant spatial spillovers from a municipality to its neighbors. Omitting to take them into account may reduce the efficiency of our estimates and bias them.

To address this issue, we estimate a spatial model by means of the generalized spatial two stage least squares (GS2SLS) estimator of Kelejian and Prucha (1998). Results are presented in table 6 , which reproduces the more complete specification used in of table 2 . We employ both a non-standardized (columns 1 to 3 ) and a row-standardized (columns 4 to 6) contiguity matrix. We implement a spatial error model (columns 1 and 4), a spatial autoregressive model (columns 2 and 5) and a model that combines the two by considering both a spatial lag and a spatial error structure (columns 3 and 6). ${ }^{4}$

Spatial analysis is consistent with our baseline estimates. Interestingly, the autoregressive coefficients on the spatial structure are almost always significant, suggesting that mafia's activity in neighboring municipalities is indeed relevant and thus spatial estimates are justified. Yet, the sign of the spatial lag is robust across specifications. The main result of the spatial analysis is that, across all specifications, mafia measures are always positively and significantly related to the share of votes of Forza Italia, with a point estimated which is very close to the one estimated in table 2 .

\footnotetext{
${ }^{4}$ If neighboring units have similar intercepts due to their proximity, spatial dependence appears only in the error term (LeSage and Pace, 2009) and a Spatial Error model (SEM) should be estimated. In that case, omitting the spatial specification of the error term would reduce efficiency of the estimator, while preserving consistency (Anselin, 1988). In turn, if mafia's density in one municipality is directly affected by mafia's activity in neighboring locations, one should estimate a Spatial Autoregressive model (SAR), which includes among regressors a spatial lag, that is, a weighted average of mafia's activity in neighboring municipalities. A (non-standardized) contiguity is a proximity matrix that associates 1 to each pair of municipalities sharing a border and 0 to any other pair (the diagonal is set to 0 by convention). Row-standardization is obtained by normalizing the sum of each row of the matrix to 1 . The difference between the first and the second case is that the spatial lag captures total and average mafia's activity in neighboring municipalities, respectively.
} 


\section{Causality}

Even after controlling for other determinants of electoral outcome and for province fixed effects, mafia presence may be correlated with the error term. Indeed, estimating the effect of mafia on elections using a simple linear regression is likely to produce biased estimates for several reasons, including reverse causality, omitted variable bias and measurement error. For instance, if mafia families chose to back Forza Italia, but the latter fought the mafia more intensively than expected, reverse causality would produce an attenuation bias. By contrast, if Forza Italia's politicians actively favored mafia activities, OLS coefficients would be upward biased due to reverse causation. Omitted variables are an obvious concern, because OLS estimates might just reflect a spurious correlation. Finally, it is possible that mafia's presence is mismeasured. Indeed, seized firms and real estates do not just depend on mafia activity, but also on the success of law enforcement and on judicial strategies. We tackle these problems in differnt ways. First, the use of predetermined mafia measures, especially those dating back to the end of the XIX century, reduces reverse causality concerns. Second, to minimize measurement errors, we rely on dummies for mafia presence, rather than exploiting more noisy information on the intensity of mafia activity. Moreover, the consistency of our results across different mafia mesures reduces concerns for measurement errors. Third, we show the robustness of our results across different specifications of the set of controls. This attenuates the likelihood that we are picking up spurious correlations. Yet, ultimately, endogeneity concerns call for an instrumental variable strategy.

\subsection{IV strategy}

De Feo and De Luca (2013) instrument contemporary mafia using the measure of mafia intensity constructed by Cutrera (1900). We come close to this strategy when using Cutrera's data on mafia presence as an explanatory variable for today's vote shares, in a sort of reduced form regression. Yet, in light of mafia's persistence, one possible concern about the validity of mafia' historical distribution as an instrument for its current presence is that both might in principle be related to omitted variables that are correlated with electoral outcomes.

We look for instruments that are predictors of mafia's historical and contemporary distribution, but that are unlikely to be related to current electoral outcomes through any other channel. We follow Buonanno et al. (2014) and propose three instruments: the number of sulfur mines in each municipality in 1886 from Squarzina (1963), soil suitability for the cultivation of cereals, obtained by the FAO-GAEZ database, and difference in elevation within a municipality, from ISTAT. As discussed in Buonanno et al. (2014), these characteristics are strongly correlated with mafia's early distribution and, due to persistence, to its current distribution. At the same 
time, they capture characteristics which have very little economic and social relevance, so that they are unlikely to bear any relation to electoral outcomes through any other channel.

Sulfur became Sicily's most valuable export good in the XIX century, when the island arrived to account for more than $80 \%$ of the world's sulfur production. World demand of Sicilian sulfur increased rapidly after the Industrial Revolution, raising the demand for protection in the areas of sulfur mines. The first documented mafia-type criminal organization, the Brotherhood of Favara (Dickie, 2004), was located in the heart of the sulfur-producing area and many of its members worked in the sulfur industry at different levels. Buonanno et al. (2014) document the existence of a systematic causal link from sulfur availability to mafia's emergence (and persistence) in Sicilian municipalities. At the same time, world demand for Sicilian sulfur also rapidly declined in the XX century, due to technical change that made sulfur in other parts of the world cheaper. Today, Sicilian sulfur industry is more a memory from the past than an active sector.

Agro-ecological suitability for cereals - determined in large part by exogenous soil properties and climatic conditions - is significantly related to mafia distribution because, as noticed by several historians and recently documented by Pazzona (2010), cereals and extensive cultivations (associated with landholdings) played a relevant role in mafia's emergence. Yet the agrarian reform in 1950 significantly downplayed the role of large landholdings. At the same time, today only $8 \%$ of Sicily's cultivated land is devoted to cereal production, whose value is only a minor share of the island's GDP. Moreover, we do not measure actual production, but rather exogenous agro-ecological suitability, which is unlikely to be related to contemporary electoral outcomes through other channels.

Finally, difference in elevation, measured by the maximum difference in altitude in a given municipality, played a relevant role in the past, when it imposed significant limitations on both agriculture and cattle breeding activities (Michalopoulos, 2012; Grigg, 1995; Lupo, 1993), it raised the cost of policing and offered criminals better possibilities to hide and control the territory. While for these reasons it is significantly related to mafia distribution, it is unlikely that such aspects play a role for current electoral outcomes through other channels.

Once equipped with these set of instruments for mafia presence, we proceed to analyze the effects on electoral vote shares. Table 7 shows the results of our IV estimation that include province-fixed effects and the list of controls previously described. The first stage regression, reported in Table 8 confirms that our instruments fit well. Sulfur, difference in elevation and suitability for the cultivation of cereals are often strongly significant and with the expected sign. IV diagnostic shows the relevance of the instruments. The underidentification test (KleibergenPaap statistics) confirms that our estimations do not suffer from a weak instrument, as well as all regression models are supported by the Hansen $\mathbf{J}$ statistic (over identification test) which confirms that our instruments used are valid.

Overall, 2SLS estimates are qualitatively and quantitatively consistent with the OLS results. 
Nevertheless, the magnitude of our IV estimates is higher than the corresponding OLS ones. In particular, the mafia presence is associated with a $9 \%$ increase in the share of votes for Forza Italia and with a $2 \%$ reduction in the share of votes obtained by the centre-left coalition despite the latter is not significant. It is worth noticing that our findings are stable across specification and are consistent with the different measure of mafia used.

\section{Discussion and conclusions}

This paper presents evidence, based on disaggregated data from the Italian region of Sicily, that between 1994 and 2008 Silvio Berlusconi's party, Forza Italia, obtained more votes in municipalities plagued by mafia. It further argues that, coherently with testimonies by former mafia lords, this correlaion is likely to reflect an explicit choice by mafia families to back Forza Italia in exchange for more favorable policies. The evidence in favor of this interpretation comes from an instrumental variable strategy, in which mafia's presence is instrumented by three determinants of its early diffusion in the late XIX century, namely the presence of sulfur caves, difference in elevation within a municipality, and agro-ecological suitability for cereals. None of these results holds if one tries to relate the votes obtained by the centre-left coalition to mafia presence.

This evidence sheds light on one the channels through which mafia organizations may sucure their own persistence in a democracy, despite the fact that most of the voting population would be better off without mafia, namely by supplying votes to political parties in exchange for favorable policies. By showing that historically predicted mafia presence raises a specific party's vote shares at political elections, this paper contributes to the developing literature on mafia and politics. Its main implication is that a successful strategy against mafia should take into account its activity in the market for votes. If citizens' votes are controlled by the mafia through violence or its threat, and then sold to lenient politicians, the latter are unlikely to actively destroy one of the sources ot their own power and career. 


\section{References}

Acemoglu, D., J. A. Robinson, and R. J. Santos (2013). The monopoly of violence: Evidence from Colombia. Journal of the European Economic Association 11, 5-44.

Anselin, L. (1988). Spatial Econometrics: Methods and Models. Dordrecht: Kluwer Academic Publishers.

Baland, J.-M. and J. A. Robinson (2008). Land and power: Theory and evidence from Chile. American Economic Review 98(5), 1737-65.

Barone, G. and G. Narciso (2014). Organized crime and business subsidies: Where does the money go? Mimeo, Trinity College Dublin.

Buonanno, P., R. Durante, G. Prarolo, and P. Vanin (2014). Poor institutions, rich mines: Resource curse in the origins of the Sicilian mafia. Economic Journal, forthcoming.

Comando Generale dell'Arma dei Carabinieri (1987). Relazione del comandante generale dell'arma dei carabinieri alla commissione parlamentare sul fenomeno della mafia.

Corbetta, P. and M. S. Piretti (2009). Atlante storico-elettorale d?Italia (1861-2008). Bologna: Zanichelli.

Cutrera, A. (1900). La mafia e i Mafiosi. Reber, Palermo.

Damiani, A. (1885). Relazione del Commissario Abele Damiani, Deputato al Parlamento, sulla Prima Circoscrizione (Provincie di Caltanissetta, Catania, Girgenti, Messina, Palermo, Siracusa e Trapani. In S. Jacini (Ed.), Atti della Giunta per la Inchiesta Agraria e sulle Condizioni della Classe Agricola. Forzani e C., Tipografi del Senato. Anastatic reprint by Arnaldo Forni Editore in 1987.

De Feo, G. and G. De Luca (2013). Mafia in the ballot box. SIRE Discussion Papers 2013-104, Scottish Institute for Research in Economics (SIRE).

Dekel, E., M. O. Jackson, and A. Wolinsky (2008). Vote Buying: General Elections. Journal of Political Economy 116(2), 351-380.

Dickie, J. (2004). Cosa Nostra. A history of the Sicilian Mafia. Palgrave Macmillan, New York.

Esteban, J. and D. Ray (2006). Inequality, lobbying, and resource allocation. American Economic Review 96(1), 257-279. 
Gambetta, D. (1993). The Sicilian Mafia: the business of private protection. Harvard University Press.

Geys, B. and G. Daniele (2014). Organized crime, institutions and political quality: Empirical evidence from Italian municipalities. Economic Journal, forthcoming.

Grigg, D. (1995). An introduction to agricultural geography. Routledge.

Grossman, G. M. and E. Helpman (1996). Electoral Competition and Special Interest Politics. Review of Economic Studies 63(2), 265-86.

Kelejian, H. H. and I. R. Prucha (1998). A generalized spatial two-stage least squares procedure for estimating a spatial autoregressive model with autoregressive disturbances. Journal of Real Estate Finance and Economics 17(1), 99-121.

LeSage, J. and R. K. Pace (2009). Introduction to Spatial Econometrics. London: CRC Press, Taylor \& Francis Group.

Lupo, S. (1993). Storia della mafia dalle origini ai nostri giorni. Donzelli, Roma.

Michalopoulos, S. (2012). The origins of ethnolinguistic diversity. American Economic Review 102(4), 15081539.

Pazzona, M. (2010). Emerging classes and the fight for resources: an empirical investigation into the origins of the sicilian mafia. Working paper.

Piketty, T. (1999). The information-aggregation approach to political institutions. European Economic Review 43(4-6), 791-800.

Piketty, T. (2000). Voting as Communicating. Review of Economic Studies 67(1), 169-91.

Pinotti, P. (2014). The economic cost of organized crime: Evidence from southern italy. Economic Journal, forthcoming.

Snyder, J. M. (1991). On buying legislatures. Economics \& Politics 3(2), 93-109.

Squarzina, F. (1963). Produzione e Commercio dello Zolfo in Sicilia nel Secolo XIX. Industria Libraria Tipografica Editrice, Torino.

Sylos Labini, P. (2003). Le radici della mafia in sicilia. In P. Sylos Labini and G. Arena (Eds.), Scritti sul mezzogiorno (1954-2001). Piero Lacaita Editore, Manduria-Bari-Roma. 


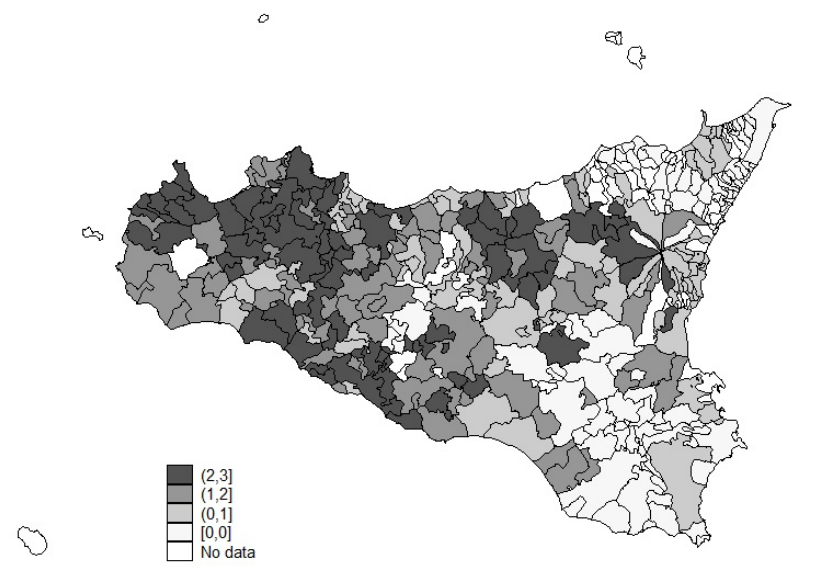

Fig. 1: Geographic Distribution of the Sicilian Mafia in the Late XIX Century

Notes. The figure reports the assessment of the intensity of mafia activity according to Cutrera, with darker greys indicating more intense mafia's activity (missing values are reported in white). Missing values correspond to cases for which it was not possible to match historical municipalities (or districts) to current ones, e.g. for municipalities created in the XX century. 


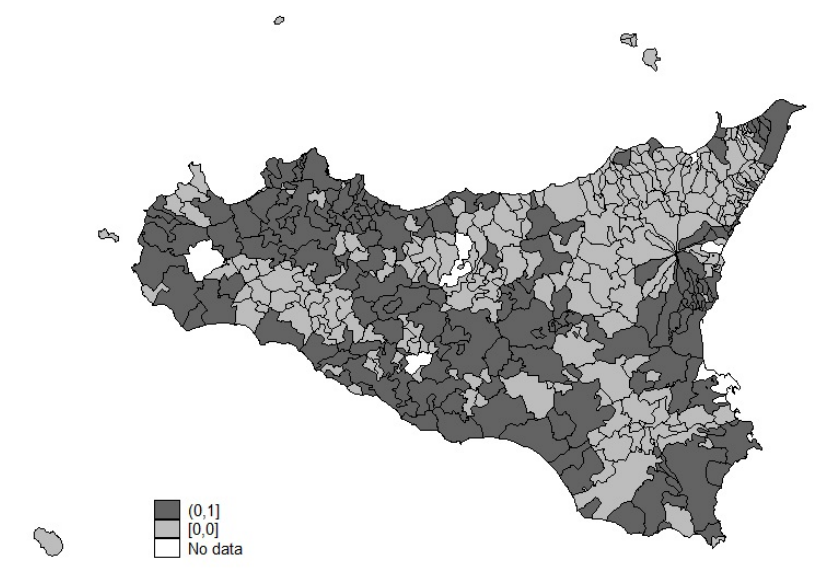

Fig. 2: Geographic Distribution of the Mafia-Related Seizures in 2011

Notes. The figure shows the geographical distribution of the dummy variable indicating whether at least a firm or a real estate/property have been seized by the Italian judicial authority in each municipality by the end of 2011 (source: Agenzia del Demanio). 


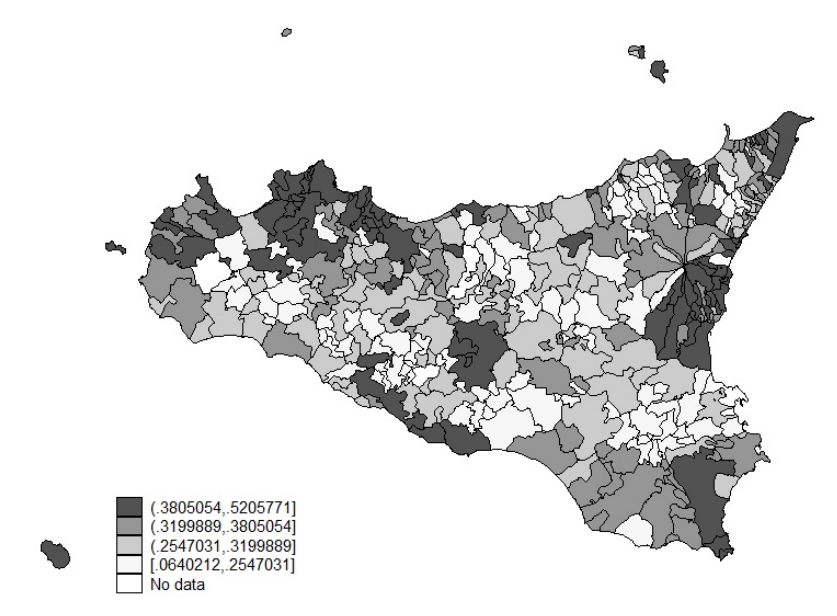

Fig. 3: Geographic Distribution of the Forza Italia's Vote Share

Notes. The figure reports the distribution of the average vote shares obtained by Forza Italia in the 1994 to 2008 elections. 
Table 1: Descriptive Statistics

\begin{tabular}{lccccc}
\hline Variable & Obs & Mean & Std. Dev. & Min & Max \\
\hline Seized real estates & 383 & 0.40 & 0.49 & 0 & 1 \\
Seized firms & 383 & 0.21 & 0.41 & 0 & 1 \\
Seizure (total) & 383 & 0.41 & 0.49 & 0 & 1 \\
mafia_1987 & 375 & 0.22 & 0.42 & 0 & 1 \\
mafia_cutrera & 337 & 0.70 & 0.46 & 0 & 1 \\
Pop. density & 383 & 336.48 & 636.86 & 3.52 & 5503.20 \\
Immigration & 383 & 1.61 & 1.50 & 0.13 & 15.74 \\
High school & 383 & 20.28 & 4.66 & 10.02 & 37.91 \\
TV fee evasion & 383 & 0.43 & 0.11 & 0 & 0.90 \\
Unemp. rate & 383 & 14.28 & 2.89 & 8.39 & 24.54 \\
GDP per capita & 383 & 11061.02 & 3653.08 & 4998.72 & 20093.51 \\
Caves & 391 & 1.32 & 5.70 & 0 & 61.00 \\
Difference in elevation & 390 & 774.88 & 532.84 & 40.00 & 3282.00 \\
Cereals suitability & 389 & 16.51 & 11.13 & 0 & 66.38 \\
\hline
\end{tabular}

Notes. Descriptive statistics of the main variables used in the empirical analysis. Data is at the municipality level except for $g d p_{-} r$ that is collected at the Local System of Labor. 
Table 2: OLS estimates using contemporary measures of mafia

\begin{tabular}{|c|c|c|c|c|c|c|c|c|c|}
\hline & (1) & (2) & (3) & (4) & (5) & (6) & (7) & (8) & (9) \\
\hline Seized real estates & $\begin{array}{c}0.0482 * * * * \\
{[0.009]}\end{array}$ & $\begin{array}{c}0.0494 * * * \\
{[0.006]}\end{array}$ & $\begin{array}{c}0.0332 * * * \\
{[0.006]}\end{array}$ & & & & & & \\
\hline Seized firms & & & & $\begin{array}{c}0.0494 * * * \\
{[0.010]}\end{array}$ & $\begin{array}{c}0.0451 * * * * \\
{[0.006]}\end{array}$ & $\begin{array}{c}0.0267 * * * * \\
{[0.007]}\end{array}$ & & & \\
\hline Seizure (total) & & & & & & & $\begin{array}{c}0.0495 * * * * \\
{[0.008]}\end{array}$ & $\begin{array}{c}0.0514 * * * \\
{[0.005]}\end{array}$ & $\begin{array}{c}0.0360 * * * \\
{[0.007]}\end{array}$ \\
\hline Pop. density & & & $\begin{array}{c}0.0222 * * \\
{[0.007]}\end{array}$ & & & $\begin{array}{c}0.0225 * * * \\
{[0.007]}\end{array}$ & & & $\begin{array}{c}0.0215 * * \\
{[0.007]}\end{array}$ \\
\hline Immigration rate & & & $\begin{array}{l}0.0056 \\
{[0.005]}\end{array}$ & & & $\begin{array}{l}0.0067 \\
{[0.005]}\end{array}$ & & & $\begin{array}{l}0.0056 \\
{[0.005]}\end{array}$ \\
\hline High school & & & $\begin{array}{l}-0.0098 \\
{[0.132]}\end{array}$ & & & $\begin{array}{l}0.0309 \\
{[0.125]}\end{array}$ & & & $\begin{array}{c}-0.0171 \\
{[0.133]}\end{array}$ \\
\hline TV fee evasion & & & $\begin{array}{l}4.2408 \\
{[9.437]}\end{array}$ & & & $\begin{array}{l}4.3858 \\
{[9.481]}\end{array}$ & & & $\begin{array}{l}4.1799 \\
{[9.113]}\end{array}$ \\
\hline Unemp. rate & & & $\begin{array}{l}0.0825 \\
{[0.295]}\end{array}$ & & & $\begin{array}{l}0.1457 \\
{[0.316]}\end{array}$ & & & $\begin{array}{l}0.0891 \\
{[0.286]}\end{array}$ \\
\hline GPD per capita & & & $\begin{array}{l}0.0022 \\
{[0.001]}\end{array}$ & & & $\begin{array}{l}0.0021 \\
{[0.001]}\end{array}$ & & & $\begin{array}{c}0.0022 \\
{[0.001]}\end{array}$ \\
\hline Average altitude & & & $\begin{array}{l}-0.0223 \\
{[0.035]}\end{array}$ & & & $\begin{array}{l}-0.0229 \\
{[0.039]}\end{array}$ & & & $\begin{array}{l}-0.0230 \\
{[0.035]}\end{array}$ \\
\hline Prov. FE & $\mathrm{N}$ & Y & Y & $\mathrm{N}$ & $\mathrm{Y}$ & Y & $\mathrm{N}$ & $\mathrm{Y}$ & $\mathrm{Y}$ \\
\hline Observations & 383 & 383 & 382 & 383 & 383 & 382 & 383 & 383 & 382 \\
\hline R-squared & 0.077 & 0.209 & 0.284 & 0.057 & 0.180 & 0.269 & 0.082 & 0.217 & 0.290 \\
\hline
\end{tabular}

Notes. This table presents the results of OLS estimates. The dependent variable is the average share of votes obtained at national elections by Forza Italia over the period 1994-2008. The three main explanatory variables are dummies indicating whether at least one firm (or at least one real estate property, or at least one of either of the two, respectively) had been seized to the mafia in a given municipality (source: Agenzia del Demanio), while the other control variables are described in the main text. Robust standard errors (clustered at the province level when province dummies are introduced) are presented in parentheses. $*$, ** and $* * *$ denote rejection of the null hypothesis of the coefficient being equal to 0 at $10 \%, 5 \%$ and $1 \%$ significance level, respectively. 
Table 3: OLS estimates using historical measures of mafia

\begin{tabular}{|c|c|c|c|c|c|c|}
\hline & $(1)$ & $(2)$ & (3) & (4) & (5) & (6) \\
\hline mafia_1987 & $\begin{array}{l}0.0157 \\
{[0.011]}\end{array}$ & $\begin{array}{c}0.0265^{* * *} * \\
{[0.006]}\end{array}$ & $\begin{array}{c}0.0221 * * \\
{[0.007]}\end{array}$ & & & \\
\hline mafia_cutrera & & & & $\begin{array}{c}0.0118 \\
{[0.010]}\end{array}$ & $\begin{array}{l}0.0183 \\
{[0.023]}\end{array}$ & $\begin{array}{c}0.0131 \\
{[0.012]}\end{array}$ \\
\hline Pop. density & & & $\begin{array}{c}0.0239 * * \\
{[0.008]}\end{array}$ & & & $\begin{array}{c}0.0356 * * \\
{[0.014]}\end{array}$ \\
\hline Immigration rate & & & $\begin{array}{l}0.0056 \\
{[0.005]}\end{array}$ & & & $\begin{array}{l}0.0045 \\
{[0.004]}\end{array}$ \\
\hline High school & & & $\begin{array}{l}0.0896 \\
{[0.106]}\end{array}$ & & & $\begin{array}{l}0.1294 \\
{[0.117]}\end{array}$ \\
\hline TV fee evasion & & & $\begin{array}{l}4.5036 \\
{[9.680]}\end{array}$ & & & $\begin{array}{l}3.9417 \\
{[8.206]}\end{array}$ \\
\hline Unemp. rate & & & $\begin{array}{l}0.1179 \\
{[0.316]}\end{array}$ & & & $\begin{array}{l}0.1585 \\
{[0.310]}\end{array}$ \\
\hline GDP per capita & & & $\begin{array}{c}0.0024 * \\
{[0.001]}\end{array}$ & & & $\begin{array}{l}0.0015 \\
{[0.001]}\end{array}$ \\
\hline Average altitude & & & $\begin{array}{c}-0.0238 \\
{[0.038]}\end{array}$ & & & $\begin{array}{c}-0.0156 \\
{[0.039]}\end{array}$ \\
\hline Prov. FE & $\mathrm{N}$ & $\mathrm{Y}$ & $\mathrm{Y}$ & $\mathrm{N}$ & $\mathrm{Y}$ & $\mathrm{Y}$ \\
\hline Observations & 375 & 375 & 374 & 337 & 337 & 336 \\
\hline R-squared & 0.006 & 0.159 & 0.270 & 0.004 & 0.160 & 0.274 \\
\hline
\end{tabular}

Notes. This table presents the results of OLS estimates. The dependent variable is the average share of votes obtained at national elections by Forza Italia over the period 1994-2008. The two main explanatory variables are dummies indicating whether mafia was active according to a 1987 military police report to a parliamentary committee (Comando Generale dell'Arma dei Carabinieri, 1987) and according to Cutrera (1900), respectively. The other control variables are described in the main text. Robust standard errors (clustered at the province level when province dummies are introduced) are presented in parentheses. $*, * *$ and $* * *$ denote rejection of the null hypothesis of the coefficient being equal to 0 at $10 \%, 5 \%$ and $1 \%$ significance level, respectively. 
Table 4: The effect of contemporary mafia on the share of votes of the centre-left coalition

\begin{tabular}{|c|c|c|c|c|c|c|c|c|c|}
\hline & $(1)$ & $(2)$ & (3) & (4) & $(5)$ & (6) & $(7)$ & $(8)$ & (9) \\
\hline Seized real estates & $\begin{array}{c}-0.0229 * * \\
{[0.009]}\end{array}$ & $\begin{array}{c}-0.0361 * * * \\
{[0.006]}\end{array}$ & $\begin{array}{c}-0.0245^{* *} \\
{[0.009]}\end{array}$ & & & & & & \\
\hline Seized firms & & & & $\begin{array}{c}-0.0288 * * * \\
{[0.011]}\end{array}$ & $\begin{array}{c}-0.0338 * * * \\
{[0.005]}\end{array}$ & $\begin{array}{c}-0.0192 * * \\
{[0.008]}\end{array}$ & & & \\
\hline Seizure (total) & & & & & & & $\begin{array}{c}-0.0252 * * * \\
{[0.009]}\end{array}$ & $\begin{array}{c}-0.0384 * * * \\
{[0.006]}\end{array}$ & $\begin{array}{c}-0.0276^{* *} \\
{[0.009]}\end{array}$ \\
\hline Pop. density & & & $\begin{array}{c}-0.0109^{* *} \\
{[0.004]}\end{array}$ & & & $\begin{array}{c}-0.0112^{* *} \\
{[0.004]}\end{array}$ & & & $\begin{array}{c}-0.0104 * * \\
{[0.004]}\end{array}$ \\
\hline Immigration rate & & & $\begin{array}{c}-0.0024 \\
{[0.005]}\end{array}$ & & & $\begin{array}{c}-0.0032 \\
{[0.005]}\end{array}$ & & & $\begin{array}{l}-0.0024 \\
{[0.005]}\end{array}$ \\
\hline High school & & & $\begin{array}{l}0.0201 \\
{[0.176]}\end{array}$ & & & $\begin{array}{l}-0.0107 \\
{[0.173]}\end{array}$ & & & $\begin{array}{l}0.0277 \\
{[0.179]}\end{array}$ \\
\hline TV fee evasion & & & $\begin{array}{c}-15.7090 * * * \\
{[4.359]}\end{array}$ & & & $\begin{array}{c}-15.8304 * * * \\
{[4.413]}\end{array}$ & & & $\begin{array}{c}-15.6412 * * * \\
{[4.339]}\end{array}$ \\
\hline Unemp. ate & & & $\begin{array}{c}0.1275 \\
{[0.344]}\end{array}$ & & & $\begin{array}{l}0.0810 \\
{[0.364]}\end{array}$ & & & $\begin{array}{l}0.1238 \\
{[0.338]}\end{array}$ \\
\hline GDP per capita & & & $\begin{array}{l}-0.0025 \\
{[0.002]}\end{array}$ & & & $\begin{array}{r}-0.0024 \\
{[0.002]}\end{array}$ & & & $\begin{array}{l}-0.0024 \\
{[0.002]}\end{array}$ \\
\hline Average altitude & & & $\begin{array}{l}0.0143 \\
{[0.024]}\end{array}$ & & & $\begin{array}{l}0.0149 \\
{[0.027]}\end{array}$ & & & $\begin{array}{l}0.0148 \\
{[0.024]}\end{array}$ \\
\hline Constant & $0.3198 * * *$ & $0.3250 * * *$ & $0.3925 * * *$ & $0.3168 * * *$ & $0.3179 * * *$ & $0.4002 * * *$ & $0.3210^{* * *}$ & $0.3265 * * *$ & $0.3918 * * *$ \\
\hline Prov. FE & $\mathrm{N}$ & $\mathrm{Y}$ & $\mathrm{Y}$ & $\mathrm{N}$ & $\mathrm{Y}$ & $\mathrm{Y}$ & $\mathrm{N}$ & $\mathrm{Y}$ & $\mathrm{Y}$ \\
\hline $\begin{array}{l}\text { Observations } \\
\text { R-squared }\end{array}$ & $\begin{array}{c}383 \\
0.015\end{array}$ & $\begin{array}{c}383 \\
0.209\end{array}$ & $\begin{array}{c}382 \\
0.266\end{array}$ & $\begin{array}{c}383 \\
0.017\end{array}$ & $\begin{array}{c}383 \\
0.197\end{array}$ & $\begin{array}{c}382 \\
0.258\end{array}$ & $\begin{array}{c}383 \\
0.019\end{array}$ & $\begin{array}{c}383 \\
0.215\end{array}$ & $\begin{array}{c}382 \\
0.270\end{array}$ \\
\hline
\end{tabular}

Notes. This table presents the results of OLS estimates. The dependent variable is the average share of votes obtained at national elections by the centre-left coalition over the period 1994-2008. The three main explanatory variables are dummies indicating whether at least one firm (or at least one real estate property, or at least one of either of the two, respectively) had been seized to the mafia in a given municipality (source: Agenzia del Demanio), while the other control variables are described in the main text. Robust standard errors (clustered at the province level when province dummies are introduced) are presented in parentheses. *, ** and *** denote rejection of the null hypothesis of the coefficient being equal to 0 at $10 \%, 5 \%$ and $1 \%$ significance level, respectively. 
Table 5: The effect of historical mafia on the share of votes of the centre-left coalition

\begin{tabular}{|c|c|c|c|c|c|c|}
\hline & (1) & (2) & (3) & $(4)$ & $(5)$ & (6) \\
\hline mafia_1987 & $\begin{array}{l}0.0106 \\
{[0.011]}\end{array}$ & $\begin{array}{l}-0.0053 \\
{[0.010]}\end{array}$ & $\begin{array}{c}-0.0030 \\
{[0.009]}\end{array}$ & & & \\
\hline mafia_cutrera & & & & $\begin{array}{l}0.0178 \\
{[0.011]}\end{array}$ & $\begin{array}{l}0.0041 \\
{[0.031]}\end{array}$ & $\begin{array}{c}0.0083 \\
{[0.019]}\end{array}$ \\
\hline Pop. density & & & $\begin{array}{c}-0.0118 * * \\
{[0.005]}\end{array}$ & & & $\begin{array}{c}-0.0197 * \\
{[0.010]}\end{array}$ \\
\hline Immigration rate & & & $\begin{array}{c}-0.0028 \\
{[0.005]}\end{array}$ & & & $\begin{array}{l}-0.0002 \\
{[0.004]}\end{array}$ \\
\hline High school & & & $\begin{array}{c}-0.0572 \\
{[0.163]}\end{array}$ & & & $\begin{array}{l}-0.0916 \\
{[0.185]}\end{array}$ \\
\hline TV fee evasion & & & $\begin{array}{c}-16.0909 * * * \\
{[3.851]}\end{array}$ & & & $\begin{array}{c}-15.4205^{* * * *} \\
{[3.154]}\end{array}$ \\
\hline Unemp. rate & & & $\begin{array}{l}0.0701 \\
{[0.367]}\end{array}$ & & & $\begin{array}{l}0.0307 \\
{[0.334]}\end{array}$ \\
\hline GDP per capita & & & $\begin{array}{c}-0.0026^{*} \\
{[0.001]}\end{array}$ & & & $\begin{array}{l}-0.0016 \\
{[0.001]}\end{array}$ \\
\hline Average altitude & & & $\begin{array}{c}0.0158 \\
{[0.028]}\end{array}$ & & & $\begin{array}{c}0.0103 \\
{[0.031]}\end{array}$ \\
\hline Prov. FE N & $\mathrm{Y}$ & $\mathrm{Y}$ & $\mathrm{N}$ & $\mathrm{Y}$ & Y & \\
\hline Observations & 375 & 375 & 374 & 337 & 337 & 336 \\
\hline R-squared & 0.002 & 0.181 & 0.254 & 0.008 & 0.202 & 0.269 \\
\hline
\end{tabular}

Notes. This table presents the results of OLS estimates. The dependent variable is the average share of votes obtained at national elections by the centre-left coalition over the period 1994-2008. The two main explanatory variables are dummies indicating whether mafia was active according to a 1987 military police report to a parliamentary committee (Comando Generale dell'Arma dei Carabinieri, 1987) and according to Cutrera (1900), respectively. The other control variables are described in the main text. Robust standard errors (clustered at the province level when province dummies are introduced) are presented in parentheses. *, ** and *** denote rejection of the null hypothesis of the coefficient being equal to 0 at $10 \%, 5 \%$ and $1 \%$ significance level, respectively. 
Table 6: Spatial estimates: share of votes for Forza Italia

\begin{tabular}{|c|c|c|c|c|c|c|}
\hline & (1) & (2) & (3) & (4) & (5) & (6) \\
\hline Seized real estates & $\begin{array}{c}0.0325 * * * \\
{[0.009]}\end{array}$ & & & $\begin{array}{c}0.0336 * * * \\
{[0.009]}\end{array}$ & & \\
\hline Seized firms & & $\begin{array}{c}0.0165^{*} \\
{[0.010]}\end{array}$ & & & $\begin{array}{c}0.0159 * \\
{[0.010]}\end{array}$ & \\
\hline Seizure (total) & & & $\begin{array}{c}0.0263^{* * *} * \\
{[0.008]}\end{array}$ & & & $\begin{array}{c}0.0247 * * * \\
{[0.008]}\end{array}$ \\
\hline Pop. density & $\begin{array}{c}0.0221 * * * \\
{[0.008]}\end{array}$ & $\begin{array}{c}0.0196 * * \\
{[0.008]}\end{array}$ & $\begin{array}{c}0.0188 * * \\
{[0.008]}\end{array}$ & $\begin{array}{c}0.0226 * * * \\
{[0.008]}\end{array}$ & $\begin{array}{c}0.0195^{* *} \\
{[0.008]}\end{array}$ & $\begin{array}{c}0.0194 * * \\
{[0.008]}\end{array}$ \\
\hline Immigration rate & $\begin{array}{c}0.0056^{*} \\
{[0.003]}\end{array}$ & $\begin{array}{c}0.0044 \\
{[0.003]}\end{array}$ & $\begin{array}{c}0.0037 \\
{[0.003]}\end{array}$ & $\begin{array}{c}0.0056^{*} \\
{[0.003]}\end{array}$ & $\begin{array}{c}0.0053^{*} \\
{[0.003]}\end{array}$ & $\begin{array}{c}0.0045 \\
{[0.003]}\end{array}$ \\
\hline High school & $\begin{array}{c}-0.0086 \\
{[0.100]}\end{array}$ & $\begin{array}{l}0.0137 \\
{[0.096]}\end{array}$ & $\begin{array}{c}-0.0240 \\
{[0.095]}\end{array}$ & $\begin{array}{l}-0.0110 \\
{[0.100]}\end{array}$ & $\begin{array}{l}0.0034 \\
{[0.094]}\end{array}$ & $\begin{array}{l}-0.0269 \\
{[0.093]}\end{array}$ \\
\hline TV fee evasion & $\begin{array}{l}4.0742 \\
{[3.934]}\end{array}$ & $\begin{array}{l}5.2105 \\
{[3.919]}\end{array}$ & $\begin{array}{l}5.1400 \\
{[3.885]}\end{array}$ & $\begin{array}{l}4.5305 \\
{[3.973]}\end{array}$ & $\begin{array}{l}4.8112 \\
{[3.958]}\end{array}$ & $\begin{array}{l}5.6057 \\
{[3.936]}\end{array}$ \\
\hline Unemp. rate & $\begin{array}{l}0.0759 \\
{[0.199]}\end{array}$ & $\begin{array}{c}-0.0073 \\
{[0.217]}\end{array}$ & $\begin{array}{c}-0.0661 \\
{[0.214]}\end{array}$ & $\begin{array}{c}0.0874 \\
{[0.200]}\end{array}$ & $\begin{array}{l}0.0177 \\
{[0.226]}\end{array}$ & $\begin{array}{r}-0.0129 \\
{[0.221]}\end{array}$ \\
\hline GDP per capita & $\begin{array}{c}0.0022 * \\
{[0.001]}\end{array}$ & $\begin{array}{c}0.0023 * \\
{[0.001]}\end{array}$ & $\begin{array}{c}0.0023 * \\
{[0.001]}\end{array}$ & $\begin{array}{c}0.0022 * \\
{[0.001]}\end{array}$ & $\begin{array}{c}0.0025 * * \\
{[0.001]}\end{array}$ & $\begin{array}{c}0.0026 * * \\
{[0.001]}\end{array}$ \\
\hline Average altitude & $\begin{array}{c}-0.0251 * \\
{[0.014]}\end{array}$ & $\begin{array}{c}-0.0463 * * * \\
{[0.017]}\end{array}$ & $\begin{array}{c}-0.0461 * * * \\
{[0.017]}\end{array}$ & $\begin{array}{l}-0.0221 \\
{[0.014]}\end{array}$ & $\begin{array}{c}-0.0310^{* *} \\
{[0.015]}\end{array}$ & $\begin{array}{c}-0.0310^{* *} \\
{[0.015]}\end{array}$ \\
\hline$\lambda$ & $\begin{array}{c}0.0026 \\
{[0.0044]}\end{array}$ & & $\begin{array}{l}0.0026 \\
0.0053\end{array}$ & $\begin{array}{c}-0.0210 \\
{[0.014]}\end{array}$ & & $\begin{array}{c}-0.0500 \\
{[0.0401]}\end{array}$ \\
\hline$\rho$ & & $\begin{array}{c}0.0891 * * * \\
{[0.0106]}\end{array}$ & $\begin{array}{c}0.0848 * * * \\
{[0.0110]}\end{array}$ & & $\begin{array}{l}.4600 * * * \\
{[0.0600]}\end{array}$ & $\begin{array}{c}0.4694 * * * \\
{[0.0662]}\end{array}$ \\
\hline Observations & 382 & 382 & 382 & 382 & 382 & 382 \\
\hline
\end{tabular}


Table 7: IV estimates: mafia on share of votes of Forza Italia

\begin{tabular}{|c|c|c|c|c|c|}
\hline & $(1)$ & $(2)$ & (3) & (4) & (5) \\
\hline Seized real estates & $\begin{array}{c}0.1314 * * \\
{[0.055]}\end{array}$ & & & & \\
\hline Seized firms & & $\begin{array}{c}0.1017 * * \\
{[0.050]}\end{array}$ & & & \\
\hline Seizure (total) & & & $\begin{array}{c}0.1298 * * \\
{[0.054]}\end{array}$ & & \\
\hline mafia_1987 & & & & $\begin{array}{c}0.1735^{* *} \\
{[0.080]}\end{array}$ & \\
\hline mafia_cutrera & & & & & $\begin{array}{c}0.1496 * * * \\
{[0.057]}\end{array}$ \\
\hline Pop. density & $\begin{array}{c}0.0167 * \\
{[0.009]}\end{array}$ & $\begin{array}{c}0.0184 * * \\
{[0.008]}\end{array}$ & $\begin{array}{l}0.0149 \\
{[0.009]}\end{array}$ & $\begin{array}{c}0.0250 * * \\
{[0.010]}\end{array}$ & $\begin{array}{c}0.0289 * * * \\
{[0.010]}\end{array}$ \\
\hline Immigration rate & $\begin{array}{c}0.0031 \\
{[0.004]}\end{array}$ & $\begin{array}{c}0.0073 * * \\
{[0.003]}\end{array}$ & $\begin{array}{c}0.0035 \\
{[0.004]}\end{array}$ & $\begin{array}{c}0.0040 \\
{[0.003]}\end{array}$ & $\begin{array}{c}0.0066 \\
{[0.004]}\end{array}$ \\
\hline High school & $\begin{array}{c}-0.2314 \\
{[0.161]}\end{array}$ & $\begin{array}{l}-0.0657 \\
{[0.118]}\end{array}$ & $\begin{array}{c}-0.2308 \\
{[0.159]}\end{array}$ & $\begin{array}{c}0.0522 \\
{[0.116]}\end{array}$ & $\begin{array}{l}0.1018 \\
{[0.124]}\end{array}$ \\
\hline TV fee evasion & $\begin{array}{l}1.7910 \\
{[5.776]}\end{array}$ & $\begin{array}{l}2.4865 \\
{[5.469]}\end{array}$ & $\begin{array}{c}1.8591 \\
{[5.713]}\end{array}$ & $\begin{array}{l}5.5610 \\
{[5.857]}\end{array}$ & $\begin{array}{l}3.8373 \\
{[5.608]}\end{array}$ \\
\hline Unemp. rate & $\begin{array}{c}-0.0660 \\
{[0.245]}\end{array}$ & $\begin{array}{c}0.1795 \\
{[0.247]}\end{array}$ & $\begin{array}{c}-0.0232 \\
{[0.236]}\end{array}$ & $\begin{array}{c}-0.1701 \\
{[0.329]}\end{array}$ & $\begin{array}{l}0.0246 \\
{[0.267]}\end{array}$ \\
\hline GDP per capita & $\begin{array}{c}0.0007 \\
{[0.002]}\end{array}$ & $\begin{array}{c}0.0002 \\
{[0.002]}\end{array}$ & $\begin{array}{c}0.0007 \\
{[0.002]}\end{array}$ & $\begin{array}{c}0.0020 \\
{[0.001]}\end{array}$ & $\begin{array}{l}0.0006 \\
{[0.001]}\end{array}$ \\
\hline Average altitude & $\begin{array}{c}-0.0160 \\
{[0.017]}\end{array}$ & $\begin{array}{l}-0.0191 \\
{[0.016]}\end{array}$ & $\begin{array}{c}-0.0192 \\
{[0.017]}\end{array}$ & $\begin{array}{l}-0.0283 \\
{[0.018]}\end{array}$ & $\begin{array}{c}-0.0310 * \\
{[0.019]}\end{array}$ \\
\hline Observations & 381 & 381 & 381 & 373 & 335 \\
\hline
\end{tabular}

Notes. This table presents the results of the second stage of the IV estimates. The dependent variable is the average share of votes obtained at national elections by Forza Italia over the period 1994-2008. The instrumented explanatory variable in column 1(2 and 3, respectively) is a dummy indicating whether at least one firm (real estate, or at least one of either, respectively) had been seized to the mafia in a given municipality (source: Agenzia del Demanio). In column 4 and 5 the instrumented explanatory variables are dummies indicating whether mafia was active according to a 1987 military police report to a parliamentary committee (Comando Generale dell'Arma dei Carabinieri, 1987) and according to Cutrera (1900), respectively. The other control variables are described in the main text. Province fixed effects are always included. Robust standard errors clustered at the province level are presented in parentheses. *,** and *** denote rejection of the null hypothesis of the coefficient being equal to 0 at $10 \%, 5 \%$ and $1 \%$ significance level, respectively. 
Table 8: IV estimates: first stage

\begin{tabular}{lccccc}
\hline & $(1)$ & $(2)$ & $(3)$ & $(4)$ & $(5)$ \\
\hline \multirow{2}{*}{ Caves } & & & & & \\
& $0.0079^{* *}$ & $0.0068^{*}$ & $0.0072^{* *}$ & $0.0078^{* *}$ & 0.0033 \\
Difference in elevation & {$[0.003]$} & {$[0.004]$} & {$[0.003]$} & {$[0.004]$} & {$[0.002]$} \\
& $0.1706^{* *}$ & $0.1124 *$ & $0.1758^{* *}$ & 0.0488 & $0.1583^{*}$ \\
Cereals suitability & {$[0.084]$} & {$[0.065]$} & {$[0.083]$} & {$[0.067]$} & {$[0.087]$} \\
& $0.0079^{* *}$ & $0.0100 * * *$ & $0.0085^{* *}$ & 0.0018 & $0.0093^{* * *}$ \\
& {$[0.003]$} & {$[0.003]$} & {$[0.003]$} & {$[0.003]$} & {$[0.002]$} \\
Kleibergen-Paap statistic & 14.09 & 14.75 & 14.48 & 3.78 & 17.20 \\
Hansen J statistic & 6.68 & 9.82 & 6.34 & 10.95 & 1.81 \\
& & & & & \\
Observations & 381 & 381 & 381 & 373 & 335 \\
R-squared & 0.267 & 0.246 & 0.253 & 0.338 & 0.501 \\
\hline
\end{tabular}

Notes. This table presents the results of the first stage of the IV estimates reported in Table 7. The dependent variable in column 1(2 and 3, respectively) is a dummy indicating whether at least one firm (real estate, or at least one of either, respectively) had been seized to the mafia in a given municipality (source: Agenzia del Demanio). In column 4 and 5 the dependent variables are dummies indicating whether mafia was active according to a 1987 military police report to a parliamentary committee (Comando Generale dell'Arma dei Carabinieri, 1987) and according to Cutrera (1900), respectively. The three main explanatory variables are the number of sulfur mines in each municipality in 1886 from Squarzina (1963), the suitability of soil for the cultivation of cereals, obtained by the FAO-GAEZ database, and the difference in altitude within a municipality, from ISTAT. The other control variables, not reported, are described in the main text. Robust standard errors (clustered at the province level when province dummies are introduced) are presented in parentheses. *, ** and $* * *$ denote rejection of the null hypothesis of the coefficient being equal to 0 at $10 \%, 5 \%$ and $1 \%$ significance level, respectively. 
Table 9: IV estimates: mafia on share of votes of the centre-left coalition

\begin{tabular}{|c|c|c|c|c|c|}
\hline & (1) & (2) & (3) & (4) & $(5)$ \\
\hline Seized real estates & $\begin{array}{l}-0.0465 \\
{[0.047]}\end{array}$ & & & & \\
\hline Seized firms & & $\begin{array}{c}-0.0262 \\
{[0.046]}\end{array}$ & & & \\
\hline Seizure (total) & & & $\begin{array}{l}-0.0447 \\
{[0.046]}\end{array}$ & & \\
\hline mafia_1987 & & & & $\begin{array}{c}-0.0878 \\
{[0.070]}\end{array}$ & \\
\hline mafia_cutrera & & & & & $\begin{array}{l}-0.0456 \\
{[0.052]}\end{array}$ \\
\hline Pop. density & $\begin{array}{l}-0.0094 \\
{[0.007]}\end{array}$ & $\begin{array}{l}-0.0105 \\
{[0.007]}\end{array}$ & $\begin{array}{l}-0.0088 \\
{[0.007]}\end{array}$ & $\begin{array}{l}-0.0121 \\
{[0.008]}\end{array}$ & $\begin{array}{c}-0.0164 * * \\
{[0.008]}\end{array}$ \\
\hline Immigration rate & $\begin{array}{l}-0.0019 \\
{[0.003]}\end{array}$ & $\begin{array}{l}-0.0033 \\
{[0.003]}\end{array}$ & $\begin{array}{l}-0.0020 \\
{[0.003]}\end{array}$ & $\begin{array}{l}-0.0019 \\
{[0.003]}\end{array}$ & $\begin{array}{l}-0.0011 \\
{[0.003]}\end{array}$ \\
\hline High school & $\begin{array}{c}0.0686 \\
{[0.146]}\end{array}$ & $\begin{array}{c}-0.0028 \\
{[0.114]}\end{array}$ & $\begin{array}{c}0.0654 \\
{[0.144]}\end{array}$ & $\begin{array}{c}-0.0372 \\
{[0.108]}\end{array}$ & $\begin{array}{l}-0.0807 \\
{[0.107]}\end{array}$ \\
\hline TV fee evasion & $\begin{array}{c}-15.1253 * * * \\
{[5.054]}\end{array}$ & $\begin{array}{c}-15.6168 * * * \\
{[4.897]}\end{array}$ & $\begin{array}{c}-15.1808 * * * \\
{[5.017]}\end{array}$ & $\begin{array}{c}-16.6571 * * * \\
{[5.228]}\end{array}$ & $\begin{array}{c}-15.3590 * * * \\
{[5.321]}\end{array}$ \\
\hline Unemp. rate & $\begin{array}{c}0.1558 \\
{[0.248]}\end{array}$ & $\begin{array}{l}0.0729 \\
{[0.239]}\end{array}$ & $\begin{array}{l}0.1390 \\
{[0.242]}\end{array}$ & $\begin{array}{c}0.2280 \\
{[0.303]}\end{array}$ & $\begin{array}{c}0.0781 \\
{[0.242]}\end{array}$ \\
\hline GDP per capita & $\begin{array}{l}-0.0020 \\
{[0.001]}\end{array}$ & $\begin{array}{l}-0.0021 \\
{[0.002]}\end{array}$ & $\begin{array}{l}-0.0020 \\
{[0.001]}\end{array}$ & $\begin{array}{c}-0.0023 * \\
{[0.001]}\end{array}$ & $\begin{array}{l}-0.0012 \\
{[0.001]}\end{array}$ \\
\hline Average altitude & $\begin{array}{c}0.0126 \\
{[0.015]}\end{array}$ & $\begin{array}{l}0.0141 \\
{[0.015]}\end{array}$ & $\begin{array}{c}0.0137 \\
{[0.014]}\end{array}$ & $\begin{array}{l}0.0180 \\
{[0.016]}\end{array}$ & $\begin{array}{c}0.0160 \\
{[0.016]}\end{array}$ \\
\hline $\begin{array}{l}\text { Observations } \\
\text { R-squared }\end{array}$ & $\begin{array}{c}381 \\
0.254\end{array}$ & $\begin{array}{c}381 \\
0.255\end{array}$ & $\begin{array}{c}381 \\
0.262\end{array}$ & $\begin{array}{c}373 \\
0.151\end{array}$ & $\begin{array}{c}335 \\
0.225\end{array}$ \\
\hline
\end{tabular}

Notes. This table presents the results of the second stage of the IV estimates. The dependent variable is the average share of votes obtained at national elections by the centre-left coalition over the period 1994-2008. The instrumented explanatory variable in column 1 (2 and 3, respectively) is a dummy indicating whether at least one firm (real estate, or at least one of either, respectively) had been seized to the mafia in a given municipality (source: Agenzia del Demanio). In column 4 and 5 the instrumented explanatory variables are dummies indicating whether mafia was active according to a 1987 military police report to a parliamentary committee (Comando Generale dell'Arma dei Carabinieri, 1987) and according to Cutrera (1900), respectively. The other control variables are described in the main text. Province fixed effects are always included. Robust standard errors clustered at the province level are presented in parentheses. *, ** and *** denote rejection of the null hypothesis of the coefficient being equal to 0 at $10 \%, 5 \%$ and $1 \%$ significance level, respectively. 


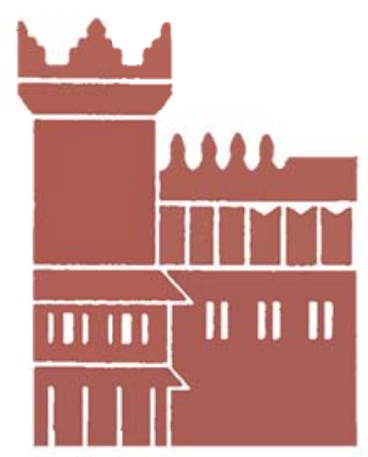

Alma Mater Studiorum - Università di Bologna DEPARTMENT OF ECONOMICS

Strada Maggiore 45

40125 Bologna - Italy

Tel. +39051 2092604

Fax +390512092664

http://www.dse.unibo.it 